Agro-Science Journal of Tropical Agriculture, Food, Environment and Extension Volume 11 Number 2 May 2012 pp 24 - 31

ISSN IIIY-7455

\title{
EFFECT OF TILLAGE AND POULTRY MANURE APPLICATION ON SOIL INFILTRATION RATE AND MAIZE ROOT GROWTH IN A SANDY ALFISOL
}

\author{
Busari M.A. and Salako F.K. \\ Department of Soil Science and Land Management, Federal University of Agriculture, P.M.B. \\ 2240, Abeokuta, Nigeria.
}

\begin{abstract}
This study was carried out in Abeokuta, South-western Nigeria in 2008 and 2009 to assess the impact of tillage and poultry manure (PM) on soil infiltration rate and maize root growth. The experiment was a split-plot design with three replications. The main plot consisted of three tillage treatments: zero tillage (ZT), minimum tillage (MT) and conventional tillage (CT) while the sub-plot comprised three PM treatments $\left(0,10\right.$ and $\left.20 \mathrm{Mg} \mathrm{ha}^{-1}\right)$. Soil infiltration characteristics were determined on the field using disc permeameter while root mass was evaluated by excavation method. In 2008, the soil infiltration rate (IR) was significantly higher under MT than other tillage systems while the IR was higher by about11\% under CT than ZT. Though, there was no significant difference in IR among the three tillage systems in 2009, IR was lower under CT by about 9\% and 3\% compared with MT and ZT, respectively. The IR of $10.87 \mathrm{~cm} \mathrm{hr}^{-1}$ observed in 2008 under the plots treated with $20 \mathrm{Mg} \mathrm{ha}^{-1}$ of PM decreased to $6.19 \mathrm{~cm} \mathrm{hr}$ in 2009 possibly due to reduction in the large pores of the sandy soil by repeated application of $20 \mathrm{Mg}$ $\mathrm{ha}^{-1}$ of PM. The implication of this is that nutrients are likely to be held against leaching when $20 \mathrm{Mg}$ ha $^{-1}$ PM is applied in a sandy soil. Root mass was insignificantly higher under MT than CT in both years of the study while root mass was lower under ZT than CT by about $26 \%$ in 2009. Plots treated with poultry manure gave significantly higher root mass than the control. Therefore, fast draining pores dominating sandy soil may be modified by application of large quantity $\left(20 \mathrm{Mg} \mathrm{ha}^{-1}\right)$ of PM to improve the soil water and nutrient holding capacities and maize root growth.
\end{abstract}

Keywords: Disc permeameter; fast draining pores; infiltration rate; maize root

\section{INTRODUCTION}

Several research activities have shown that the state of soil surface influence to a great extent its water infiltration and redistribution characteristics. One of the major farmer's practices that affect directly the state of soil surface and its properties is tillage operation. It has been reported that tillage can increase the prevalence of infiltration-limiting layers by exposing surface soil to raindrop impacts and contributing to structural degradation by creating smeared and compacted layers under the tilled layer (Silburn and Glanville, 2002) or on the surface (Li et al., 2001). According to Martinez et al. (2008) the increase in topsoil compaction under zero tillage (ZT) systems may decrease water infiltration and soil may become waterlogged under intense rainfall. Suitable tillage practices have been recommended as useful measure to improve infiltration rate and water storage (Mosaddeghi et al., 2009).

Research reports are yet to agree on the appropriateness of one tillage system or the other on soil infiltration rate. Guzha (2004) found that tilled plots had very high initial infiltration rate values which declined rapidly with time probably due to rapid structural deterioration caused by slaking and dispersion. Other studies (e.g. Pikul and Aase, 1995; Shukla et al., 2003) have found higher infiltration rates under ZT than conventional tillage (CT) because of the protection of the soil surface and the effect of soil organic 
Effect of Tillage and Poultry Manure Application on Soils

caroon. uupla el al. (LUV4) reported thal less intense tillage kept the crop residue at the soil surface thereby increased the activity of surfacefeeding earthworms, leaving the root channels undisturbed, which in turn led to the presence of numerous surface-connected macro-pores and inter-pedal voids leading to higher infiltration.

Several studies have evaluated the effect of tillage and soil amendments on root growth (Anderson, 1987; Barber, 1971) and results of such studies are diverse as to the benefit of tilled or untilled soil relative to variation in soil and climatic condition of the study area. According to Lampurlanes et al. (2001), soil physical conditions under ZT can negatively affect the growth of the main root axes, particularly, at the initial stages of plant development. Such effect may limit nutrient and water uptake (Qin et al., 2006) leading to an exponential decrease in root mass (Martino and Shaykewich, 1994). Shirani et al. (2002) reported that CT increased root penetration. However, increases in root mass have been found in the upper soil layers of ZT (Martinez et al., 2008) and reduced tillage (Lal, 1989) systems when compared to a CT system because, soil compaction of deeper soil layers under ZT may impede the optimal development of roots (Martinez et al., 2008).

Since it is clear that the response of soil infiltration and root growth to tillage depends on soil type, climate and management practice, research efforts at identifying the appropriate tillage system along side management practice that tend to reduce soil surface disruption are paramount. This study was therefore, carried out in south-western Nigeria to determine the effect of tillage and poultry manure application on soil infiltration rate and maize root development.

\section{MATERIALS AND METHODS \\ Site description}

The experiments were carried out at the University of Agriculture, Abeokuta, southwestern Nigeria in 2008 and 2009. The study area lies between Latitude $7^{\circ} 14^{\prime} \mathrm{N}$ and Longitude $3^{\circ} 26^{\prime} \mathrm{E}$ and is located within a forest-savannah transition zone (Salako et al., 2007) with two distinct seasons - the wet season, which extends from March to October, and the dry season which is usually from November to February. The rainfall is bimodal in distribution, having its peak in July and September with a short break referred to as August break. The mean annual rainfall of the study site in 2008 and 2009 was $1320 \mathrm{~mm}$ while the mean monthly temperature ranged from 30 to $37^{\circ} \mathrm{C}$ in 2008 and 28 to $34^{\circ} \mathrm{C}$ in 2009 . The mean relative humidity was $00 \%$. Ine nelu was unuer secondary regrowth of shrub dominated by Adropogon gayanus prior to the establishment for this study.

\section{Experimental design}

The experiment was a split-plot factorial design with three replications. The main plot was tillage while organic manure (poultry manure (PM)) was allotted to the sub-plot. The main plot involved three tillage treatments: zero, minimum and conventional tillage, the sub-plot consisted of three organic manure treatments: $0 \mathrm{Mg} \mathrm{ha}^{-1}, 10 \mathrm{Mg}$ $\mathrm{ha}^{-1}$ and $20 \mathrm{Mg} \mathrm{ha}^{-1} \mathrm{PM}$. Under zero tillage (ZT), no ploughing was done and weeds were controlled using herbicides (paraquat). In the minimum tillage (MT), ploughing was done once while conventional tillage (CT) involved ploughing followed by harrowing. The ploughing was done on $20^{\text {th }}$ May, 2008 followed by harrowing two weeks later. The tillage operations were not carried out before application of poultry manure in 2009 but the weeds were cleared manually under MT and CT and with the aid of paraquat under ZT. Each plot was $4 \mathrm{~m} \times 5 \mathrm{~m}$ with each plot separated by $1 \mathrm{~m}$ border. About $4 \mathrm{~m}$ margins were left on both sides of each main plot fortractor to maneuver without entering into an adjacent plot.

\section{Application of poultry manure}

The poultry manure (PM) used for the experiment was collected from a poultry house operating a battery cage system. The cured PM was applied at $10 \mathrm{Mg} \mathrm{ha}^{-1}\left(\mathrm{PM}_{10}\right)$ and $20 \mathrm{Mg} \mathrm{ha}^{-1}$ $\left(\mathrm{PM}_{20}\right)$ and was incorporated into the soil two weeks before planting under the MT and CT with hand hoe while it was spread evenly on the soil surface under the ZT to ensure less surface disturbance. Application of PM was done in June 2008 for the first cropping year and was repeated in May 2009 for the second cropping year. Furrow dikes were made manually round each plot to prevent nutrient drifting among plots. The poultry manure used contained $264 \mathrm{~g} \mathrm{~kg}^{-1}$ organic carbon, $21.4 \mathrm{~g} \mathrm{~kg}^{-1}$ total nitrogen, $40.2 \mathrm{~g} \mathrm{~kg}^{-1}$ total phosphorus, $1.2 \mathrm{~g} \mathrm{~kg}^{-1}$ total potassium and $27.2 \mathrm{~g}$ $\mathrm{kg}^{-1}$ calcium.

\section{Maize planting and root mass determination \\ Maize (DMR-ESR-Y) was planted two} weeks after application of PM at a spacing of 50 $\mathrm{cm} \times 75 \mathrm{~cm}$ at 2 seeds per hole. The maize was harvested at 12 weeks after planting (WAP) in both years of cropping. Root mass was determined at 4,8 and 12 WAP using excavation method (Bohm, 1979). This was done by digging out 0-20 $\mathrm{cm}$ soil from $25 \mathrm{~cm} \times 25 \mathrm{~cm}$ area. Soil adhering to 
the roots was removed and the root samples washed with water and oven dried at $65^{\circ} \mathrm{C}$ to constant weight.

\section{Measurement of infiltration characteristics} Unsaturated water flow in the field was measured per plot with a disc permeameter. Procedure described in the manual by CSIRO (1988) was used to set up the disc permeameter on the field. Volumetric soil water content (using time domain reflectometer) was determined at the beginning and end of each infiltration run. The water head applied was $-2 \mathrm{~cm}$. Cumulative infiltration (CI) and steady state flow (SSF) were calculated from the equation given by CSIRO (1988) as follows:

$$
\mathrm{Cl}=\left[\frac{\mathrm{Q}}{\pi \mathrm{r}^{2}}\right]=\frac{\left(\mathrm{SR}-\mathrm{SR}_{1}\right)(\mathrm{RC})}{\pi \mathrm{r}^{2}} \ldots \ldots \ldots \ldots . . . . .(1)
$$

Where SR is the scale reading at the time of measurement; $\mathrm{SR}_{1}$ is the initial scale reading

$\mathrm{RC}$ is the reservoir calibration.

$$
\mathrm{SSF}=\frac{(\text { scale increment })(\text { calibration })}{(\text { area })(\text { average } \Delta \mathrm{t})} \cdots
$$

Sorptivity (S) was obtained as the slope of CI plotted against the square root of time.

The hydraulic conductivity $\left(K_{o}\right)$ during the infiltration runs was determined using equation

$$
K_{o}=\frac{\pi \mathrm{r}^{2} \mathrm{q}-4 \mathrm{~b} S_{o}^{2}}{\pi \mathrm{r}\left(\theta_{\mathrm{o}}-\theta_{\mathrm{n}}\right)}
$$

Where, q is steady state flow rate, b is a constant, $S_{o}$ is sorptivity, $\theta_{o}$ and $\theta_{n}$ are volumetric water contents at measurement and initial potentials, respectively.

Infiltration rate (IR) was determined using Philips' equation (Philips, 1957).

\section{Statistical analysis}

Data collected were analyzed using analysis of variance (ANOVA) MIXED MODEL procedure in Statistical Analysis System (SAS, 1999). The sources of variation for the ANOVA were tillage, manure, replicate and tillage $\mathrm{x}$ manure. The significance of the main and interaction effects was determined and significant means were separated using the least significant difference (LSD) at 5\% level of probability.

\section{RESULTS AND DISCUSSION}

Soil physical properties at the onset of the study

Before ploughing the soil used for the study in 2008, the gravelly loamy sand soil had a bulk density of $1.24 \mathrm{~g} \mathrm{~cm}^{-3}$, total porosity of $53.21 \%$, saturated hydraulic conductivity of $7.26 \mathrm{~cm} \mathrm{hr}^{-1}$ and volumetric water content of $8.98 \%$.

\section{Effects of tillage on field unsaturated water flow}

In 2008, all the measured unsaturated water flow parameters were significantly higher under MT than other tillage systems (Table 1). Also, cumulative infiltration (CI) and sorptivity were significantly higher under CT than ZT while steady state flow (SSF), unsaturated hydraulic conductivity $\left(K_{o}\right)$ and the infiltration rate $(I R)$ were about $11 \%$ higher under CT compared with ZT. However, in 2009, all the unsaturated water flow parameters were not significantly different among the tillage treatments but were in the order of $\mathrm{MT}>\mathrm{ZT}>\mathrm{CT}$ (Table 1). The lower infiltration rate $(I R)$ and unsaturated water flow (UWF) parameters under ZT in the first year of the study could be attributed to topsoil compaction under ZT system which may decrease water infiltration (Martinez et al., 2008). The fast draining macro-pores created by CT could also, have facilitated infiltration momentarily after tillage, but these pores reduced as a result of repackaging of soil aggregates (Martinez et al., 2008) resulting in higher $I R$ and other UWF parameters under ZT than CT at the end of the second year after tilage. Rainfall induced pore sealling (Mubarak et al., 2009) could also be implicated for lower $I R$ under CT in the second year of the study. The minimum tillage which maintained the highest $I R$ and UWF parameters (CI, sorptivity, SSF, and $K_{o}$ ) after each of the two years of the study compared with ZT and CT could be due to the fact that apart from breaking compact soil surface which may slow down water infiltraion, less intense tillage (MT) ensures the presence of numerous surfaceconnected macro-pores and inter-pedal voids leading to higher infiltration (Gupta et al., 2004). 


\section{Effects of poultry manure on field unsaturated water flow}

After 2008 cropping, the $I R$ and other unsaturated water flow (UWF) parameters were significantly raised by manure treatments than the control (Table 2). The reverse was, however, the case after 2009 cropping as the control plots had significantly higher $I R$ and UWF parameters than both levels of manure treatment. The SSF, $K_{o}$ and the $I R$ were higher with $\mathrm{PM}_{20}$ application than $\mathrm{PM}_{10}$ in 2008 but were lower with $\mathrm{PM}_{20}$ application than $\mathrm{PM}_{10}$ after 2009 cropping (Table 2). The decrease in $I R$ of plots treated with $\mathrm{PM}_{20}$ from $10.87 \mathrm{~cm} \mathrm{hr}^{-1}$ in 2008 to $6.19 \mathrm{~cm} \mathrm{hr}^{-1}$ in 2009 and the significantly lower $I R$ and the other UWF parameters in manured than the control plots in 2009 may be due to reduction in the large pores of the sandy soil by repeated application of $20 \mathrm{Mg}$ ha ${ }^{1}$ of poultry manure. Application of poultry manure significantly raised $I R$ and UWF parameters after the first year of the study because organic matter usually increases the entry of water by protecting the soil aggregates from breaking down by the impact of infiltrating water. According to FAO (1985) classification, if a soil has $I R$ of $5 \mathrm{~cm} \mathrm{hr}^{-1}$ it is considered high in $I R$ and the $I R$ of the unmanured soil in this study was $8.55 \mathrm{~cm} \mathrm{hr}^{-1}$ while that of the manured soil was $9.94-10.87 \mathrm{~cm}$ $\mathrm{hr}^{-1}$ (Table 2) in 2008. Thus, the increase in the $I R$ of the soil by manure treatments further accentuated already rapid rate of water intake in the soil due to the porous nature of the soil. The net effect of this rapid water movement was the possible nutrient leaching beyond the root zone. Again, the manure increased water infiltration in the soil during the first year of the study, apparently because aggregates had not been well formed with defined hierarchy (Oades and Walters, 1991) and proper enmeshing effect with gravelly loamy sand soil skeletons had not taken place. However, the repeated application of poultry manure in the second year which resulted in significantly lower $I R$ and UWF parameters than the control was in response to reduction in large pores (macropores) apparently due to microbial growth with a concomitant increase in physical entanglement by fungal hyphae and the production of extracellular polysaccharides capable of linking soil particles together (Haynes and Naidu, 1998). The implication of this in this porous soil is that nutrients are likely to be held against leaching when manure is applied especially at higher rate (e.g $20 \mathrm{Mg} \mathrm{ha}^{-1}$ ). This was clearly indicated by higher SSF, $K_{o}$ and the $I R$ with $\mathrm{PM}_{20}$ application than $\mathrm{PM}_{10}$ in 2008 but lower SSF, $K_{o}$ and the $I R$ with $\mathrm{PM}_{20}$ application than $\mathrm{PM}_{10}$ in 2009. Reduction in infiltration rate in response to reduction in large pores (macropores) by ash deposit following bush burning has also been reported by Are et al. (2009).

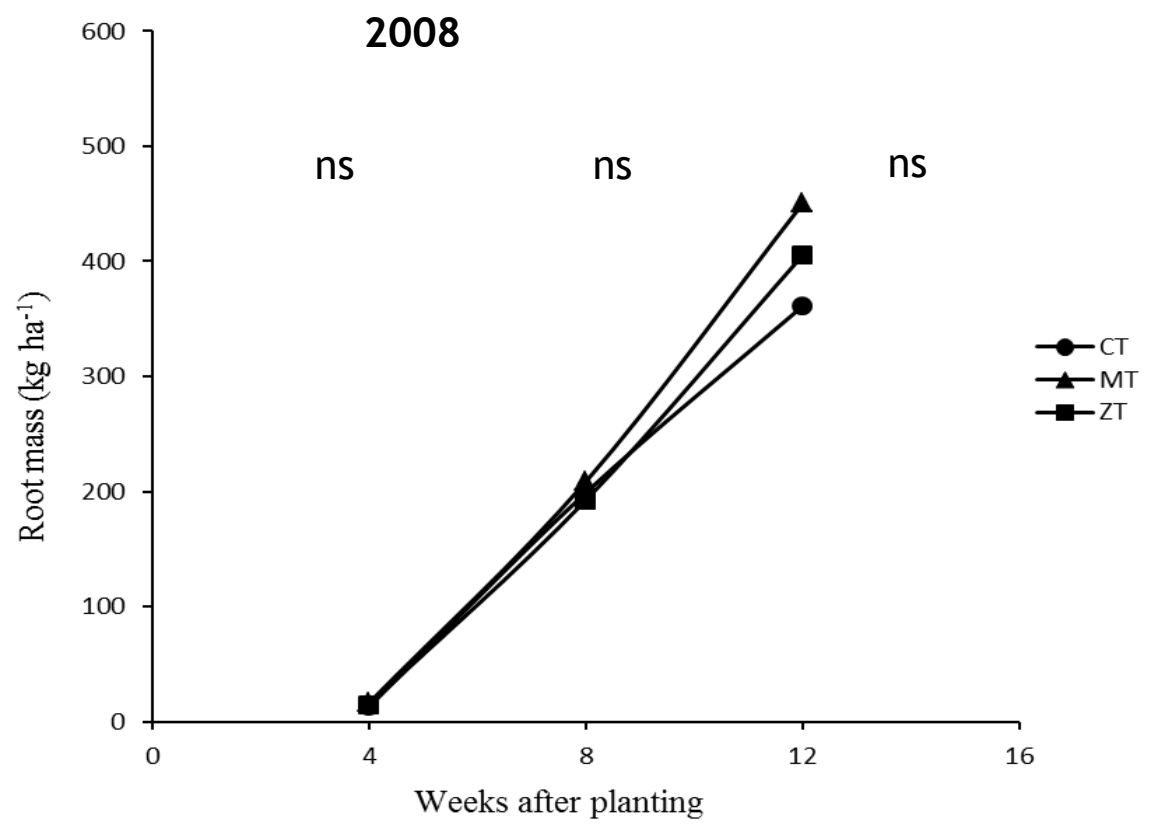




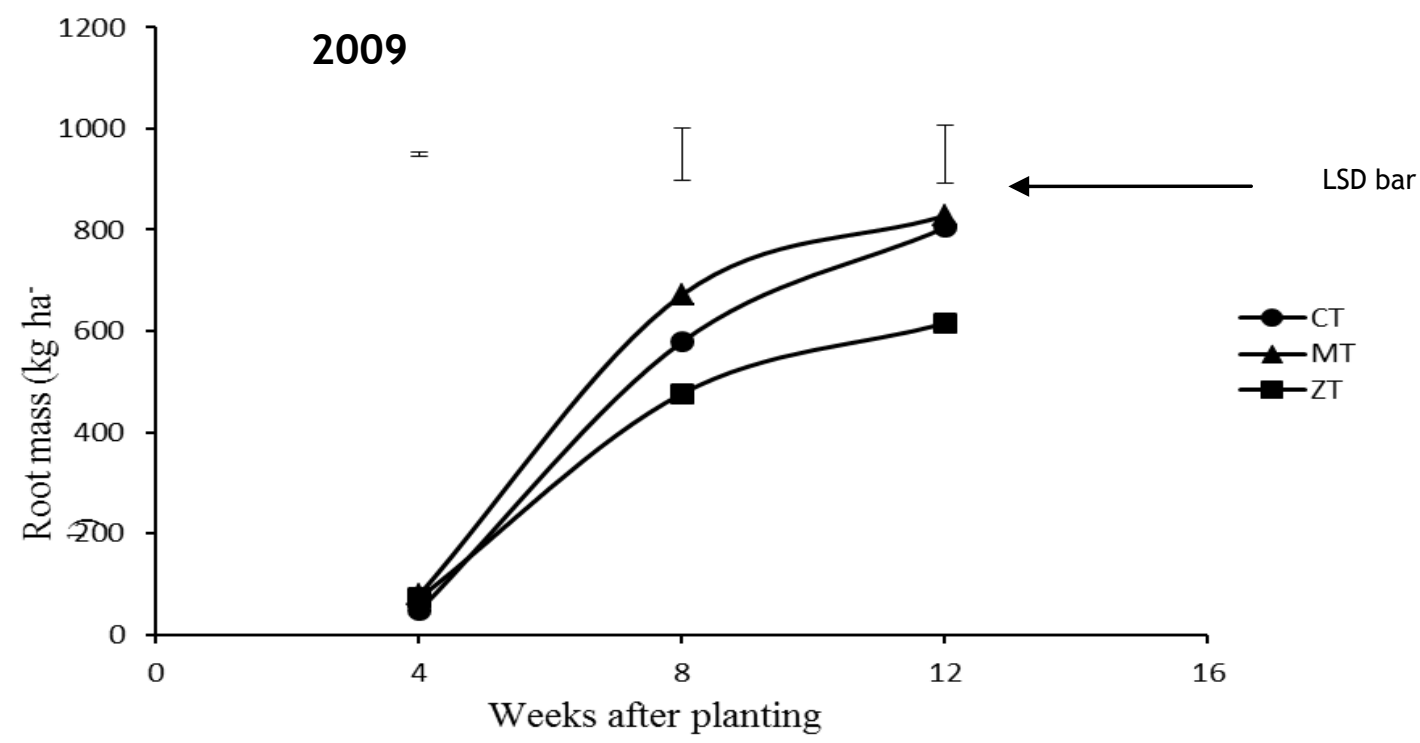

Figure 1: Effect of tillage on root mass during the 2008 and 2009 cropping $\mathrm{ns}=$ not significant

Table 1: Effect of tillage on field unsaturated water flow at the end of each of the two years of the study

\begin{tabular}{|c|c|c|c|c|c|c|c|c|c|c|}
\hline Year & & & 2008 & & & & & 2009 & & \\
\hline Tillage & $\begin{array}{l}\mathrm{CI} \\
(\mathrm{cm})\end{array}$ & $\begin{array}{l}\text { Sorptivity } \\
\left(\mathrm{cm} \mathrm{hr}^{-1 / 2}\right)\end{array}$ & $\begin{array}{l}\text { SSF } \\
\left(\mathrm{cm} \mathrm{hr}^{-1}\right)\end{array}$ & $\begin{array}{l}K_{o} \\
\left(\mathrm{~cm} \mathrm{hr}^{-1}\right)\end{array}$ & $\begin{array}{l}I R \\
\left(\mathrm{~cm} \mathrm{hr}^{-1}\right)\end{array}$ & $\begin{array}{l}\text { CI } \\
(\mathrm{cm})\end{array}$ & $\begin{array}{l}\text { Sorptivity } \\
\left(\mathrm{cm} \mathrm{hr}^{-1 / 2}\right)\end{array}$ & $\begin{array}{l}\text { SSF } \\
\left(\mathrm{cm} \mathrm{hr}^{-1}\right)\end{array}$ & $\begin{array}{l}K_{o} \\
\left(\mathrm{~cm} \mathrm{hr}^{-1}\right)\end{array}$ & $\begin{array}{l}I R \\
(\mathrm{~cm} \mathrm{hr} \\
\left.{ }^{1}\right)\end{array}$ \\
\hline CT & 3.32 & 3.55 & 9.17 & 8.50 & 9.53 & 2.15 & 2.41 & 6.40 & 6.09 & 7.12 \\
\hline MT & 3.93 & 3.79 & 10.98 & 10.25 & 11.34 & 2.30 & 2.46 & 7.02 & 6.69 & 7.79 \\
\hline $\mathrm{ZT}$ & 2.87 & 3.13 & 8.11 & 7.59 & 8.50 & 2.15 & 2.45 & 6.79 & 6.46 & 7.35 \\
\hline LSD $(P \leq 0.05)$ & 0.36 & 0.22 & 1.23 & 1.18 & 1.23 & ns & ns & ns & ns & Ns \\
\hline
\end{tabular}

CI - cumulative infiltration; SSF - steady state flow; $K_{o}$ - unsaturated hydraulic conductivity; $I R$ - infiltration rate; ns - not significant

\section{Effects of tillage on maize root mass}

During the 2008 cropping, there was no significant differences in maize root mass among the tillage systems though root mass under MT was consistently higher than other tillage treatments in all the sampling periods (Figure 1). Root growth rate diminished after 8 WAP in 2009 cropping, however, at 12 WAP root masses of 828 $\mathrm{kg} \mathrm{ha} \mathrm{a}^{-1}$ (MT) and $804 \mathrm{~kg} \mathrm{ha}^{-1}$ (CT) were significantly higher than root mass of $615 \mathrm{~kg} \mathrm{ha}^{-1}$ for ZT (Figure 1). The significantly lower root mass obtained under ZT compared with tilled plots suggested that soil compaction of deeper soil layers under ZT impeded root development and the growth of the main root axes (Lampurlanes et al., 2001; Martinez et al., 2008) while conventional tillage increased root penetration (Shirani et al., 2002). The observed diminished root growth after 8 WAP could be due to the fact that net root production is usually complete around flowering when transition from vegetative to reproductive growth occurs (Liedgens et al., 2000). Also, the start of ear growth has been shown to influence dry weight of maize root (Wagner et al., 1995) due to remobilization of nitrogen from maize root (Fusseder, 1987) to the reproductive part. 
Effect of Tillage and Poultry Manure Application on Soils
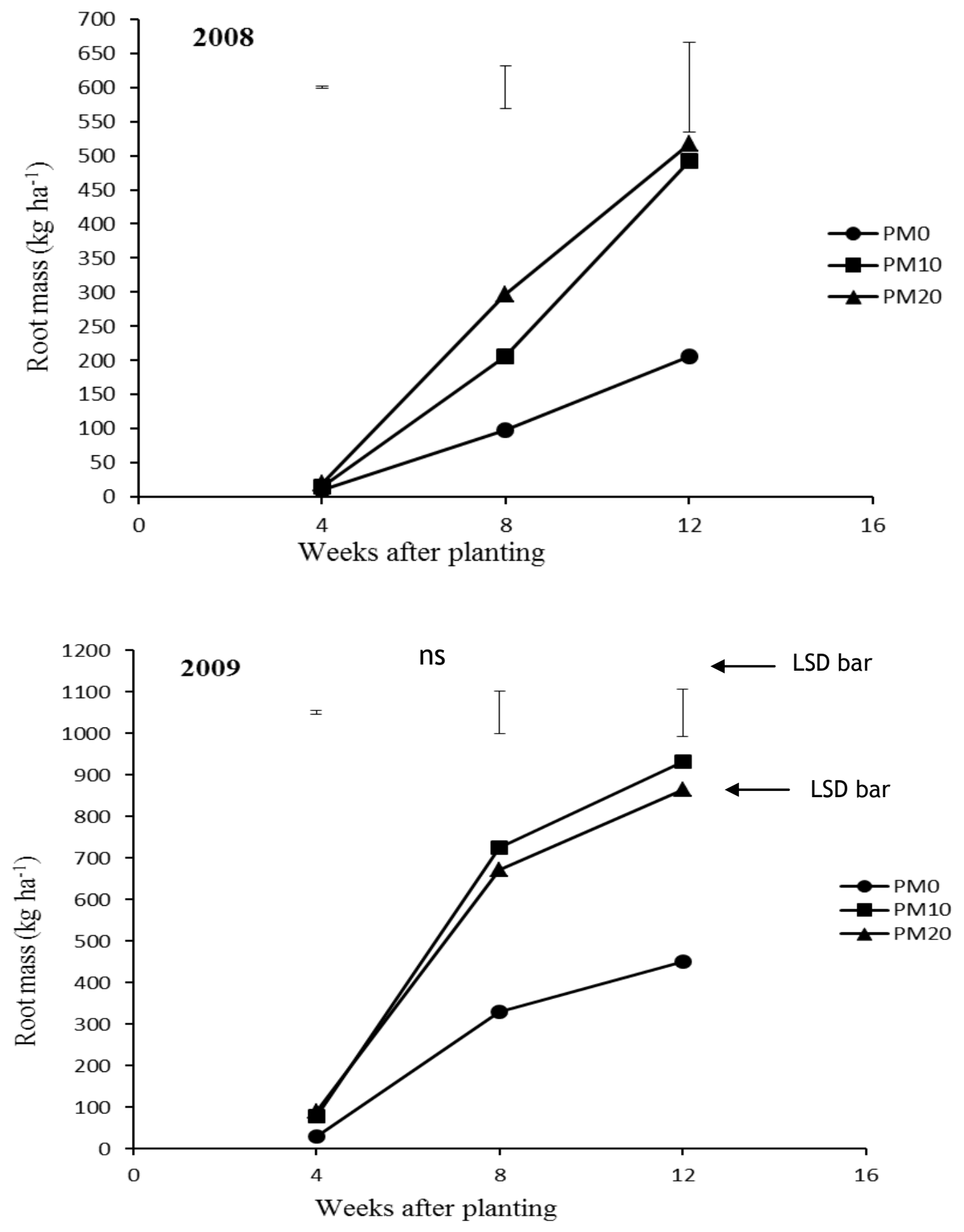

Figure 2: Effect of poultry manure on root mass during the 2008 and 2009 cropping 
Table 2: Effect of poultry manure on field unsaturated water flow at the end of each of the two years of the study

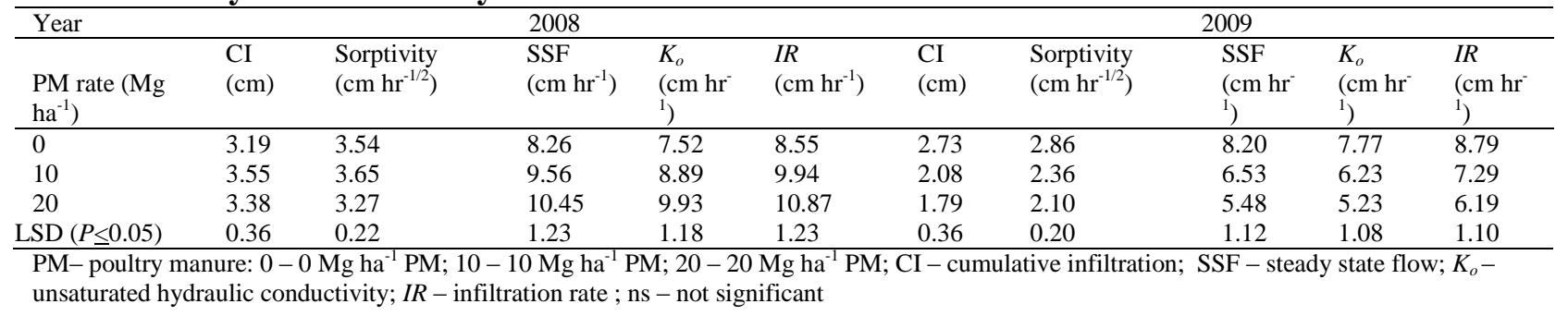

Effects of poultry manure on maize root mass

Application of either the 10 or $20 \mathrm{Mg} \mathrm{ha}^{-1} \mathrm{PM}$ significantly improved maize root development than the control in all the periods of sampling and at both years of the experiment (Figure 2). For instance, relative to the control plots, the use of $20 \mathrm{Mg} \mathrm{ha}^{-1} \mathrm{PM}$ led to $47 \%, 67 \%$ and $60 \%$ increases in root mass at 4,8 and 12 WAP, respectively in 2008 while it led to $68 \%$, $51 \%$ and $48 \%$ increases in 2009. At 4 WAP, plots treated with $20 \mathrm{Mg} \mathrm{ha}^{-1} \mathrm{PM}$ had root mass of $19.58 \mathrm{~kg}$ $\mathrm{ha}^{-1}$ (2008) and $90.90 \mathrm{~kg} \mathrm{ha}^{-1}$ (2009) which were significantly higher than $14.89 \mathrm{~kg} \mathrm{ha}^{-1}$ (2008) and $77.83 \mathrm{~kg} \mathrm{ha}^{-1}$ (2009) given by $10 \mathrm{Mg} \mathrm{ha}^{-1} \mathrm{PM}$ treated plots. However, the two rates did not cause significant difference in root mass at 12 WAP in the two years of the study (Figure 2). The significant increases in maize root mass at all the sampling periods by PM treatments could have resulted from modification of soil physical properties that improved the root environment and stimulated plant growth (Kononova, 1961). The possible increase in soil organic matter content by poultry manure which is likely to have created a new topsoil environment with better and more stable aggregates might have favour root development (Martinez et al., 2008). Higher maize root biomass in plots that received poultry manured compared with unamended plots has also been reported by Salako et al. (2007).

\section{CONCLUSION}

Infiltration characteristics were observed to be higher immediately following conventional tillage operation which decline with time apparently due to rainfall induced pore sealing. Application of poultry manure, especially at $20 \mathrm{Mg} \mathrm{ha}^{-1}$ could serve as a good soil amendment for reducing rapid percolation of water in a gravelly sandy soil thereby creating a strong possibility of minimizing nutrient leaching. From the study, mechanical impedance under zero tillage might reduce maize root growth compared with conventional tillage, minimum tillage alongside application of poultry manure was shown to be the most sustainable technique for improving maize root development.

\section{REFERENCES}

Are, K.S., Oluwatosin, G.A., Adeyolanu, O.D. and Oke, A.O. (2009). Slash and burn effect on oil quality of an Alfisol: Soil physical properties. Soil and Tillage Research 103: 4-10.

Anderson, E.L. (1987). Corn root growth and distribution as influenced by tillage and nitrogen fertilization. Agronomy Journal 79: 544-549.

Barber, S.A. (1971). Effect of tillage practice on corn (Zea mays L.) root distribution and morphology. Agronomy Journal 63:724-726.

Bohm, W. (1979). Methods of studying root systems. Ecological studies. Springer-Verglag, Berlin. Volume 33, pp 188.

Commonwealth Scientific and Industrial Research Organisation (CSIRO). (1988). CSIRO Disc Permeameter. Instruction Manual. The CSIRO Center for Environmental Mechanics, Canberra.Food and Agricultural Organization (FAO). (1985). Irrigation water management, Training manuals - 1, R4082/E.

Fusseder, A. (1987). The longevity and activity of the primary root of maize. Plant and Soil 101:257-265.

Gupta, S., Munyankusi, E., Moncrief, J., Zvomuya, F., and Hanewall, M. (2004). Tillage and Manure Application Effects on Mineral Nitrogen Leaching from Seasonally Frozen Soils. Journal of Environmental Quality 33:12381246.

Guzha, A.C. (2004). Effects of tillage on soil microrelief, surface depression storage and soil water storage. Soil and Tillage Research 76:105-114.

Haynes, R.J. and Naidu, R. (1998). Influence of lime, fertilizer and manure applications on soil organic matter content and soil physical conditions: a review. Nutrient Cycling in Agroecosystems 51:123-137.

Kononova, M.M. (1961). Soil Organic Matter: Its nature and its role in soil formation and in 
soil fertility. Pergamon Press, New York, USA pp 450.

Lal, R. (1989). Conservation tillage for sustainable agriculture: tropics vs. temperate environments. Advances in Agronomy 42:85197.

Lampurlanes, J., Angas, P. and Cantero-Martınez, C. (2001). Soil bulk density and penetration resistance under different tillage and crop management systems and their relationship with barley root growth. Field Crops Research 69:27-40.

Li, Y., Tullberg, J.N. and Freebairn, D.M. (2001). Traffic and residue cover effects on infiltration. Australian Journal of Soil Research 39:239-247.

Liedgens, M., Soldati, A., Stamp, P. and Richner, W. (2000). Root Development of Maize (Zea mays L.) as Observed with Minirhizotrons in Lysimeters. Crop Science 40:1665-1672.

Martınez E., Fuentes, J., Silva, P.,Valle, S. and Acevedo, E. (2008). Soil physical properties and wheat root growth as affected by notillage and conventional tillage systems in a Mediterranean environment of Chile. Soil and Tillage Research 99:232-244.

Martino, D.L. and Shaykewich, C.F. (1994). Root penetration profiles of wheat and barley as affected by soil penetration resistance in field conditions. Canadian Journal of Soil Science 74:193-200.

Mosaddeghi, M.R., Mahboubi, A.A. and Safadoust, A. (2009). Short-term effects of tillage and manure on some soil physical properties and maize root growth in a sandy loam soil in western Iran. Soil and Tillage Research 104: 173-179.

Mubarak, I., Mailhol, J.C., Angulo-Jaramillo, R., Ruelle, P., Boivin, P. and Khaledian, M.(2009). Temporal variability in soil hydraulic properties under drip irrigation. Geoderma 150:158-165

Oades, J.M. and Walters, A.G. (1991). Aggregate hierarchy in soils. Australia Journal of Soil Research 11:37-108.

Philips, J.R. (1957). The theory of infiltration. 1. The infiltration equation and its solution. Soil Science 83:345-357.
Philips, J.R. (1969). The theory of infiltration. Advance Hydroscience, 5:215-290. Pikul, J.L., Jr. and Aase, J.K. (1995). Infiltration and soil properties as affected by annual cropping in the northern Great Plains. Agronomy Journal 87:656-662.

Qin, R., Stamp, P. and Richner, W. (2006). Impact of tillage on maize rooting in a Cambisol and Luvisol in Switzerland. Soil and Tillage Research 85:50-61.

Salako, F.K., Dada, P.O., Adejuyigbe, C.O. Adedire, M.O., Martins O., Akwuebu, C.A.and Williams, O.E. (2007). Soil strength and maize yield after topsoil removal and application of nutrient amendments on a gravelly Afisol toposequence. Soil and Tillage Research 94:21-35.

SAS, (1999). SAS/STAT User's Guide. Version 8. Statistical Analysis System Institute Inc., Cary, NC, USA.

Shirani, H., Hajabbasi, M.A., Afyuni, M. and Hemmat, A. (2002). Effects of farmyard manure and tillage systems on soil physical properties and corn yield in central Iran. Soil and Tillage Research 68:101-108.

Shukla, M.K., Lal, R.B., Owens, L. and Unkefer, P. (2003). Land use management impacts on structure and infiltration characteristics of soils in the north Appalachian region of Ohio. Soil Science 168:167-177.

Silburn, D.M. and Glanville, S.F. (2002). Management practices for control of runoff losses from cotton furrows under storm rainfall. I. Runoff and sediment on a black Vertosol. Australian Journal of Soil Research 40:1-20.

Wagner, G.H., Buyanovsky, G.A. and Jarecki, M.K. (1995). Distribution of ${ }^{14} \mathrm{C}$ following field labelling of maize. pp. 467-474. In Nuclear techniques in soil-plant studies for sustainable agriculture and environmental preservation. International Atomic Energy Agency (IAEA), Vienna. 